\title{
DOES SOCIALLY COMMITTED BANK MANAGER MANIPULATE EARNINGS THROUGH DICRETIONARY ACCRUALS? EMPIRICAL EVIDENCE FROM AN EMERGING ECONOMY
}

\author{
MASHIUR RAHMAN ${ }^{* 1,2}$, SITI ZALEHA ABDUL RASID ${ }^{1}$ AND ROHAIDA BASIRUDDIN ${ }^{1}$ \\ ${ }^{1}$ UTM International Business School (UTM-IBS), 54100, Kuala Lumpur, Malaysia. ${ }^{2}$ University of Science and Technology, \\ Dhaka, Bangladesh.
}

*Corresponding author: mashiur1953@gmail.com

Submitted final draft: 26 April $2020 \quad$ Accepted: 8 June 2020

http://doi.org/10.46754/jssm.2020.12.012

\begin{abstract}
This paper aims to examine the relationship between corporate social responsibility reporting and earnings management. Precisely, we examine whether higher corporate social responsibility disclosures firms are gratified to perform in an accountable manner to restrain earnings management practices, thereby reporting higherquality earnings to investors. The use of the generalised method of moments estimator for a Bangladeshi sample of 270 listed banking companies for the period 2009 to 2017 investigates the association between corporate social responsibility disclosures and earnings quality proxied by discretionary accruals. Results show that managers in an emerging economy manage earnings when they provide more CSR disclosures. Furthermore, Shariah compliant banks provide more corporate social responsibility information and maintain superior financial reporting quality through constraining earnings management. The outcomes of this research are noteworthy for both policymakers and market participants. Investors need to be cautious from the point of view that businessess engage in corporate social responsibility activities, behave ethically and provide transparent financial reports. Hence, policy makers need to be vigilant about this opportunistic practice and improve observing to implement social agreement. Probably, some strategies can be introduced to settle that corporate social responsibility revelations are grounded on genuine exercise and not just a "greenwash" proclamation to mislead shareholders.
\end{abstract}

Keywords: Sustainability, corporate social responsibility reporting, earnings management, discretionary accruals, shariah principles.

Abbreviations: [ DACC, CSR, IBs, EM]

\section{Introduction}

CSR reports encompass information regarding a wide range of issues and practices associated with a corporation's dealings with its clients, contractors, and personnel about public assistance, safety, and workplace wellbeing, and public safety (Suyono \& Farooque, 2018). A consequence of joining CSR undertakings is an organisation's positive status among interested parties who will support its construction of communal bonds and reputation capital, improving its capability to engage in constructive agreements with suppliers and governments, to charge best value for services and goods, and reduce the cost of capital (Amar et al., 2018). The growing significance of sustainability, worldwide, has focused attention on CSR (Yip et al., 2011). Thus, it is inevitable that firms that perform CSR actions will deliver clear and trustworthy economic evidence.

In 2008, Bear, Stearns and Co. Inc., and Lehman Brothers were found to be one of the most admired, esteemed, and resilient financial corporations in a survey by the Wall Street Journal (Grougiou et al., 2014). These organisations were also found to be the most respected banks in the USA as they reached the highest two places within the financial sector in a survey by Fortune magazine in 2007 (Fortune, 2007), which is one of the most esteemed reviews in the world (Grougiou et al., 2014). In 2008, both institutions (banks) were on the edge of collapse as a result of being accused of providing poor financial disclosures that deceived users of organisation financial conditions (Jones, 2012). These occurrences advanced thoughtful research queries about whether the quality of financial reporting i.e., 

earnings management and CSR, are by some means linked and whether this relationship expedites the decision-making procedures of business groups (Grougiou et al., 2014). Prior research has validated that financial reporting quality, as substituted by earnings management (EM) practices, is connected to CSR (Chih et al., 2008; Prior et al., 2008).

Accounting incomes regularly mention performance figures, which are of the utmost concern to external investors, workforces, suppliers, clients, communities, and supervisory bodies (Prior et al., 2008; Chahine et al., 2018). Preferably, financial reporting assists in presenting financial decision making to shareholders and allows profitable businesses to differentiate themselves from loss concerns (Muttakin et al., 2014). Nevertheless, accounting for revenue in terms of maintaining GAAP (generally accepted accounting principles), executives can apply some discretion, causing stated revenues to appear superior to the real scenario (Prior et al., 2008). Indeed, the study of Watts and Zimmerman (1978) defined EM as executives exercising their discretion over accounting numbers. Moreover, this interference in financial statement analysis and reporting procedures may be performed to either stimulate contractual results that depend on stated accounting figures or deceive stakeholders about the actual commercial performance of a business (Kim et al., 2012).

Uncertain of the future of individual payback, sensible managers should not become involved in EM. There are two opposite perspectives on whether incentives are determined opportunistically or over the longterm (transparent financial reporting) between financial reporting comprehensibility and CSR reporting. Transparent financial reporting takes a long-term view that the evidence delivered to a company's stakeholder's effects their decision making. From this perspective, socially responsible firms are inclined to foster longterm relationships with stakeholders rather than maximize their short-term benefits. In support of the long-term (transparent financial reporting) perspective hypothesis, Hong and Andersen (2011) demonstrated that firms that engage in socially responsible activities provide more extensive financial disclosures than firms that rarely engage in such activities.

Nonetheless, previous research on EM has acknowledged three sets of incentives that motivate this practice, which are contractual engagements, capital markets, and regulatory incentives (Jones, 2012; Mersni \& Othman, 2015). These intentional actions of management act to camouflage the actual worth of a transaction, corporate asset, or monetary situation, which have adverse effects on employees, shareholders, external company environment, and society as well as executive occupation security, social status, and profession (Leventis \& Dimitropoulos, 2012; Prior et al., 2008). As protection against stakeholder vigilance and activism, managers try to compensate stakeholders in terms of CSR practices; however, if stakeholders notice these unethical practices, it may cost executives their job and harm the organisation's status (Prior et al., 2008; Choi et al., 2013). This optimistic appearance may help organisations inaugurate communal bonds and form reputation capital, refining their capability to create agreements with national regulatory authorities and suppliers, to charge superior prices for goods and services, and shrink their costs (Abdelsalam et al., 2016). Under such an arrangement, in earnings manipulation, CSR is applied as an opportunistic instrument (Kim et al., 2012).

Besides, accounting scandals prevent financial information contained in financial statements from being reliable, understandable and comparable. Thus, frauds realised on financial statements play an important role in accounting scandals. This is especially the case for frauds, which take place at enterprises, mainly due to ineffective implementation of corporate governance and internal controls (Khan \& Akter, 2017). Besides, one of the causes of these collapses has been attributed to ethical breakdowns (Gras-Gil et al., 2016). While these incidents have given rise to the imposition of 
regulations requiring companies to increase accountability and restore public trust, there has been a parallel development of sustainable regulations that require companies to provide additional information to relevant stakeholders. Thus the above points of view indicated that in environments without strong investor protection, complex ownership structures of business groups may create opportunities for expropriating minority shareholders and masking this practice through earnings management.

On the other hand, in the financial reporting realm, banks have been more prone to EM practices than nonfinancial organisations (Amidu et al., 2014). Their diversified financial operations and products, such as derivative financial instruments, are characterised by great opacity and information asymmetry which essentially complicates their financial reporting processes and makes EM practices less discernible to vigilant stakeholders and analysts (Amar et al., 2018). This study investigates an emerging market, banking sector of Bangladesh, where it is characterised by concentrated ownership, poor monitoring and governance system and weak investor protection environments, which make conflict of interest between controlling and minority shareholders a key governance issue (Kilic et al., 2015; Muttakin et al., 2017). However, from prior research it is evident that banking sector discloses more CSR information than other sectors (Ullah et al. 2015).

Though prior studies discussed the relationship between CSR and EM from the perspectives of corporate governance (Muttakin et al., 2015) and ownership structure (Prior et al., 2008 ) in the context of non-financial sectors and developed nations. However, there is a dearth of research about the relationship between CSR and EM in the overall banking sector, both the conventional and Islamic banks. Thus, it is crucial to investigate whether CSR-oriented firms produce true and fair financial information in their annual reports (long-term perspective) or merely use CSR as an opportunistic tool to mislead stakeholders to disguise true financial position of the firm (opportunistic perspective). Therefore, this study aimed to mitigate this research gap.

Moreover, previous studies have demonstrated that for directing business undertakings, religion is a prospective source of moral codes and conducts (Tafti et al., 2012; Kolsi \& Grassa, 2017). In justifying the relationship between ethical decrees and religion in corporate bodies, researchers agree that religion has significant effect in reducing wicked deeds (Elnahass et al., 2014). In terms of the effect of religion in moderating EM, contemporary studies show a positive stimulus from Shariah ethical rules on financial reporting quality (Alsaadi et al., 2013). Firms which offer Shariah amenable products or services are Shariah obedient, which is a mandatory expectation and therefore the basic exercises of these organisations are Shariah-compliant (Ibrahim et al., 2015). An assessment of the current literature discloses a dearth of research on earning quality and CSR reporting from a Shariah principle perspective. Specifically, whether CSR firms that are Shariah-compliant perform morally by providing excellent financial reporting and providing consistent information to stakeholders through the moderating effect of Shariah principles, measured by a dummy variable (Shariah-compliant banking sectors).

For the purpose of this research, we examined the association between the magnitude of CSR reporting and EM proxied by discretionary accruals (DACC) in Bangladeshi listed banking companies during the period 2009 to 2017. Hypothesis were formulated on the relationship between CSR reporting and earnings management. Results of the hypothesis testing indicate that CSRR had a significant positive relationship with earnings management. Discussion on these results is summed up in later part of this study. It is observed that the Shariah based banks disclosing extensive CSR activities are less likely involved in EM practices. This is consistent with the notion that Shariah compliant firms behave ethically and maintain high quality financial information. 
This study has numerous significant contributions to the contemporary studies regarding CSR reporting and earnings management. First, international CSR reporting frameworks such as Global Reporting Initiatives (GRI), UN Global Compact etc., have been developed to maintain uniform sustainability reporting standards all over the world, but the implications of these reporting guidelines are very narrow in the perspectives of the developing nations where sustainability reporting is still voluntary (Muttakin et al. 2015; Belal et al. 2015). Thus, this study focused on Bangladesh to examining the nature and extent of CSR disclosure based on international guidelines. Second, this study enhances the literature on CSR revelations by constructing a comprehensive disclosure index (methodological contribution) using GRI guidelines and prior research on CSR in banking sector, which has typically been concerned on sustainability strategy, CSR policy, and CSR performance in non-financial sectors. Finally, this study also compares the financial reporting quality of the Shariah compliant firms to observe the opportunistic perspective of the bank managers. Therefore, an evaluation of the existing literature reveals that lack of these preceding Bangladeshi studies has joined the elements of CSR reporting and EM as seen from the Shariah-compliant firm's perspective. Only one study discussed the relationship between CSR disclosure and earnings management (Muttakin et al., 2015) but excluding the financial sector. Therefore, there is a dearth of research that examines the quality of earnings and CSR reporting from the interaction of Shariah principles of the overall banking sector. As Se far the authors knowledge goes, there is dearth of research of this association in the perspectivce of the ovearall banking sector (both conventional and Islamic). The result reveals that CSR committed organisations that are Shariahcompliant behave morally through presenting accurate financial disclosure by providing more consistent information to the investors because moral code or Shariah principles restrain them from doing any unethical undertakings.
Thus, this study predicts that banks that offer Islamic products and services and are perceived to have embraced the Islamic values (Shariah principles) would be more concerned with their social responsibility and would be less likely to be involved in Earnings Management in comparison to conventional counterparts. Thus the following research questions are proposed.

RQ1: What is the relationship between CSR reporting and earnings management in the Bangladeshi banking sector from 2009 to 2017 ?

RQ2: Do Shariah principles moderate the relationship between CSR reporting and earnings management in the Bangladeshi banking sector?

The rest of this study is as follows: discusses the CSR disclosures and institutional background of Bangladesh followed by the theoretical framework; next, presents the literature review and constructs the research hypotheses; and subsequently, outlines the research methodology for this study, including sample selection, data collection, measurement variables, and regression models. Then the findings of the study are discussed, which cover data analysis and sensitivity analysis using advanced statistical techniques. Finally, it discusses this study contributions, recommendations for future research, and limitations.

\section{CSR disclosures and institutional background of Bangladesh}

Bangladesh received its independence from Britain and Pakistan in 1947 and 1971, respectively. Before beginning the democratic process in the 1990s, Bangladesh was under various military regimes. The context for this study is Bangladesh, a quickly developing agricultural nation with a market-based economy (Ali \& Islam, 2014). Bangladesh was the $41^{\text {st }}$ largest economy in the global IMF survey of 2018. Besides, Bangladesh has developed and adopted several rules and regulations. These laws also monitor communal and environmental issues for companies operating in Bangladesh (Hossain \& Neogy, 2019). In reality, a weak governance, lack of proper policies and guidelines, as well 
as an absence of resilient political stimulus along with deficiency of skilled workforces and expertise hindered the implementation of these laws (Belal et al., 2015). According to Hossain et al. (2017), for sustainable development the main obstacles are a lack of synchronisation between different government ministries and environmental consciousness.

For that reason, the Bangladesh government has pledged to fight corruption and has separated the judiciary from executive authority to establish law and order as well as reduce political influences on the judiciary system in 2007 (Belal \& Cooper, 2011). To advance the private sector, several endeavours have been undertaken in terms of liberalisation, privatisation, and globalisation in third world nations (Das et al., 2015). Moreover, the current strategy of the Government of Bangladesh is to attract foreign direct investment by nurturing a lowcost labour force, giving tax incentives, cheaply suppling gas and energy, permitting unhindered withdrawal policies for foreign equity concerns, having a flexible remittance policy, establishing new export processing zones, and repatriating income and profits (Rahman et al., 2019; Hossain et al., 2017). According to EPB, (2012) report, international economists have projected that if Bangladesh can maintain its current GDP growth for the next couple of years than it may overtake Western economies by 2050 . The state of the Bangladesh economy in 2019 is judged by the performance with reference to global, macro and micro levels which presents a mixed picture (Hye, 2020). The review of the performance of Bangladesh economy at the end of 2019 gives the impression of the economy being on a knife's edge, poised between sustained growth and muddling through uncertainly. Besides, the expected GDP growth of Bangladesh is $8 \%$ in 2020 (Kibria, 2020). Therefore, it will be interesting to see which direction the economy takes from 2020 onwards.

In line with other South Asian nations, CSR has been practised in many Bangladeshi corporations. However, taking into account the importance of revealing environmental and social impacts, no requirements have been enforced or proposed by the government of Bangladesh (Azim et al., 2011). Until now, there is no distinct standard for social and environmental reporting in the Bangladesh Accounting Standard (BAS) (IASCF, 2003).

Thus, in Bangladesh, CSR is voluntary except for the disclosure of energy expenditures, which must be presented as distinct expenditures in financial statement notes under the Securities and Exchange Rules of 1987 and the Companies Act of 1994 (Ahmed et al., 2018). While CSRR is voluntary in Bangladesh, it is not shocking that only a small number of corporations have revealed their CSR activities (Khan et al., 2009). However, the CompaniesAct 1994 of Bangladesh does not oblige the mandatory disclosure of CSR actions for publicly listed corporations (Das et al., 2015). On the other hand, the government delivered a Statutory Regulatory Order (SRO) that set a maximum starting point of $20 \%$ of total income or BDT eighty million businesses CSR-allied engagements entitle them to a $10 \%$ tax rebate (Ullah et al., 2015).

Explicitly, through the procedure of regulatory guidelines of the Bangladesh Bank (BB), inspiration and other initiatives have helped to generate participation in sustainability activities through a more systematic approach since 2008 (Hossain et al., 2019). For instance, intending to start green finance, BB delivered a guideline to confirm that the financial sector has methods to reduce environmental pollution when funding new ventures (BB, 2008; Masud \& Kabir, 2016). On the other hand, Shobhani et al. (2012) described that banking companies prefer annual report as a media of communication in comparison with websites to disclose sustainability information and Islamic banks disclose more sustainability data than their conventional counterparts. The reporting information on human rights and product and service responsibility information are relatively scarce in banks' discloser (Rahman et al., 2018). Also, in the absence of self-regulating certification, the reliability of disclosed data is questionable (Muttakin et al., 2015). 
Likewise, the study of Muttakin et al. (2015), based on garments indusrtries, articulated apprehensions that the stimulus and exercise for CSR in Bangladesh stem from international pressure in terms of 'powerful' stakeholder groups such as international buyers. The findings of these studies indicate that to legitimise their actions, businesses generally practise CSR. Moreover, Hossain and Neogy (2019) demonstrated that there is a significant influence of the external stakeholders in CSR development through media coverage and highlights environmental issues that create a positive move on social and ecological awareness.

Therefore, from the above empirical analysis, this study indicates that the growing trend of CSR practices and its disclosure in Bangladesh may be attributed to several drivers. They comprise the aspiration to achieve a decent market situation and construct a good reputation in the local capital market, the globalisation effects on the domestic economy, the progress of global business to the emerging nations, pressure from international organisations (for instance the OECD, UN organisations, the ILO and the World Bank), public's ordinary consciousness, and the rise of force clusters in developed countries and at the same time, to make the organisations communally and morally accountable, the local government or public pressures are also a significant driver.

\section{Sustainable Development Goals (SDG) and Bangladesh Bank's Guidelines for Climate Change}

Sustainable Development Goals (SDGs) are a universal call to action to end poverty, defend the earth and confirm that all people enjoy harmony and comfortable circumstances. Some new essential dimensions are included in SDGs like climate change, economic inequality, sustainable consumption, peace and justice, etc. The government of Bangladesh has politically committed itself to meeting the UN-sponsored SDGs. But challenges are there. The SDGs include 17 goals and 169 targets that set out quantitative and qualitative objectives. Five out of seventeen goals of SDGs are directly and more intensively related, while some other goals are indirectly/loosely related with the activities of the banking sector of Bangladesh. As a regulatory authority, Bangladesh Bank (BB), the country's central bank, is actively working on the achievement of its related goals through inclusive and sustainable strategy and other policy measures. Corporate Social Responsibility (CSR) activities and green banking are also very importantly linked with the SDGs.

Green Bank is an ethical bank, a socially responsible bank and a sustainable bank. Green financing under green banking would make great contribution towards transition to a resource-efficient and low carbon industry i.e. green industry and green economy in general. To address climate change vulnerabilities, Bangladesh developed National Adaptation Program of Action and Climate Change Strategy and Action Plan. Also, energy efficiency has received significant attention of $\mathrm{BB}$ in recent years. Banks have been advised to finance solar energy, bio-gas plant, ETP and Hybrid Hoffman Kiln (HHK) in brick field under refinance programmes. Moreover, banks should take initiative to set absolute GHG emission reduction targets from operations, energy use and business travel. Banks should also take steps to form Climate Risk Fund to finance the economic activities of the flood, cyclone and drought prone areas. Thus, a cooperative effort of banks and other stakeholders will contribute remarkable help to cope with climate challenges in the coming years.

\section{Earnings Management Practices and Banks}

For more than two decades the concern of bank's EM has been on the global research outline. Leventis and Dimitropoulos (2012) observed a sample of US banks and found substantial indications that the DACC have been used as a vital instrument of EM. Besides, prior research using non-US banks also reached similar conclusions (Ahmed et 
al., 2018). Yasuda et al. (2004) and Grougiou et al. (2014) stated that banks involved in EM practices employ the discretionary portion of total accruals. Therefore, to investigate earnings management, this study estimates total accruals and subsequently modifies and employs the Jones model to investigate discretionary accruals for the overall banking sector. Prior research also found a signal that managers are inclined to increase DACC in time of more operating revenue so that they can capture the instability of stated earnings (Abdelsalam et al., 2016). These results are also supported by the previous empirical research concentrating on the banking companies (Grougiou et al., 2014), which all established that banks use DACC as a tool for EM. Remarkably, a significant portion of the banking companies have been involved in sustainable development initiatives (Elnahass et al., 2014). Nonetheless, banks involved in the perspective of the manipulation of earnings in time of financial reporting are comparatively more noticeable than other non-financial firms (Amidu \& Kuipo, 2014).

Banks have also expanded monetary procedures and products, for example derivatives, convertible bonds and other financial instruments, which create complication in the process of corporate disclosure and ultimately makes EM practices less apparent to attentive market participants and business experts (Grougiou et al., 2014). Leventis et al. 2012 argued that total accruals have a positive mean for US sample banks. On the other hand, Bangladeshi studies showed significant involvement in the EM practices of the non banking sector and also stated that corporate governace machanism is a significant tool to minimise these unethical practices (Muttakin et al., 2015; Khan \& Akter, 2017). However, the banking sector is regulated by the central bank though it is evident from prior studies that banks involved in earnings manipulation used existing loopholes in the generally accepted accounting principles (GAAP) or local accounting standards (Grougiou et al., 2014; Amar \& Chakroun, 2018). Thus, there is a dearth of research of the EM practices in the banking sector of
Bangladesh that is also an important motivation to select the banking sector.

On the other hand, over the last three decades, significant growth has been observed in the Islamic banking sector, especially in the MENA region, and they have already accumulated more than $\$ 1.3$ trillion in assets globally (Zainuldin et al., 2018). Looking at the issue in depth and given the principles and the structure of Islamic banks (IBs), one of the unique characteristics of Islamic finance and Islamic banks is the observation of ethical values and Shariah principles in their day-today operation (Abdelsalam et al., 2016). Ethical and moral considerations should be followed in their substance (Elnahass et al., 2014). The definition of earnings management proposed by Haniffa \& Hudaib (2007) represents an attempt at modifying financial numbers so as to either (i) mislead some stakeholders or (ii) influence contractual outcomes, and it is very clear that both incentives are loaded with the concept of opportunistic behaviour, which is prohibited in Islam (Ibrahim et al., 2015).

Furthermore, the Islamic banking system has distinct restrictions for providing the loan or any investment options. Moreover, interest is forbidden in Islam but there is no restriction of any fixed payment on deposits in terms of interest in the conventional banking system. Thus, conventional banks face greater extent of credit risk that indicates the inability to meet the requirements compliant with the agreement by the debtors. This type of failure generates huge loss and therefore turns into a threat for the bank (Kolsi et al., 2016).

Besides, the Islamic banking sector is sheltered by the Shariah Supervisory Board (SSB) as an additional cover of governance. The SSB has been serving as a screening mechanism that prohibits banks from any non-Shariah compliant investments or activities against Shariah principles (Haniffa \& Hudaib, 2007). Moreover, it ensures profits by way of Shariah principles and guidelines. The ethical scrutiny delivered by the Shariah Supervisory Board should be perceived positively by the market 
participants (Alsaadi et al., 2013) and might cause lower scrutiny by the market experts and participants and develop a clean image that IBs are less engaged in earnings manipulation through EM practices, particularly in the valuation of DACC (Ibrahim et al, 2015).

\section{Theoretical framework}

\section{Stakeholder Theory}

For the purpose of this research, stakeholder theory is the accepted paradigm to explain why companies involve themselves in socially responsible activity as a strategy to maximise their long-term return on investment and sustainable business success, by recognising the importance of each stakeholder group and incorporating this knowledge into their corporate strategy (Gras-Gil et al., 2016). An executive who desires the sustained accomplishment of the organisation has to purposefully dedicate his or her consideration to the necessities of diverse shareholders because the stakeholders control wealth that is indispensable for the survival of the business (Freeman, 1984). From this perspective, particularly in the intention to meet the requirements of the different stakeholders, conveying quality earnings is diligently linked to CSR undertakings (Choi et al., 2013). In line with this understanding, previous research validates that organisations that are more dedicated to CSR activities and disclosure are involved to a lesser extent in earnings management practice (Gras-Gil et al., 2016). Overall, the above theory considers firms as part of a wider communal system, within which they exist. Also, a firm is inclined by and, in turn, influences the society with diverse stakeholders group in which it operates (Muttakin et al., 2015). Thus, according to the stakeholder theory, CSR reporting can be construed as a mechanism for ensuring commitment to the social contract.

\section{Stakeholder Salience Theory}

According to the stakeholder salience theory, power, legitimacy, and urgency are independent attributes. For example, stockholders frequently receive the attention of managers because stockholders possess both powerful and legitimate claims on the corporation through the private property rights paradigm. Mitchell et al. (1997) introduced the term 'stakeholder salience', which is the result of the degree to which a particular stakeholder has three attributes: power, legitimacy, and urgency. The authors take Pfeffer's (1981) definition of power: "a relationship among social actors in which one social actor (A), can get another social actor (B), to do something that B would not have otherwise done". Using Suchman's (1995) definition, legitimacy is defined as "A generalized perception or assumption that the actions of an entity are desirable, proper, or appropriate within some socially constructed system of norms, values, beliefs, and definitions". Urgency refers to "the degree to which stakeholder claims call for immediate attention", on the basis of time sensitivity or criticality (Mitchell et al. 1997).

This study examines the relationship between corporate social responsibility (CSR) reporting and earnings management of the banking companies by employing Mitchell et al. (1997) stakeholder salience theory. Mitchell et al. maintained that the extent to which managers pay attention to the interests of various stakeholder groups is based on the power, legitimacy, and urgency of the claims of each group. Our investigation revealed that power is the primary attribute of stakeholder salience driving CSR. That is, in order for a firm to engage in purposeful CSR activities, the stakeholder(s) pursuing a CSR agenda must possess the power to impose such an agenda on management. Moreover, to maintain legitimacy of the Shariah principles bank managers do not manipulate earnings through opportunistic CSR activities. Based on the results of our analysis, we conclude that power and legitimacy provide sufficient stakeholder salience to promote CSR activities and retrain from earnings management motives. But urgency may not provide any impact in this relationship. Thus, bank managers make decisions taking into account the interests of all the bank's stakeholders and identify their priorities and the information that should be 
disclosed to each one. Within the context of stakeholder saliance theory, CSR practices are seen as part ofthe dialogue between the company and its stakeholders and a very successful means of negotiating these relationships that ultimately confine EM practices.

\section{Agency Theory}

From a traditional standpoint, the separation of ownership and control in modern organisations, alongside EM, provides upswing to the opportunistic movements of the manager (the agent), who may have diverse intents from the owner (the principal). From this point of view, managers pursue their paybacks through sacrificing the interests of the stakeholders and corporation in terms of EM practices and is considered as an agency problem. Accordingly, the improper financial information disclosed by managers, stockholders may create operational and financial decisions, which denote the agency costs generated or impaired by EM practices. Moreover, this type of problematic managerial undertaking can deceive market participants about the real picture of the company's financial position and market value, and mislead to take wrong investment decisions. EM is, as a result, an agency cost (Grougiou et al., 2014).

Thus, managers are concerned with short-range business performance. Consequently, they anticipate accomplishing a positive share price effect. Moreover, by involving in CSR activities, the organisation can enhance their business reputation and also develop interactions with diverse stakeholders that create a stable platform to capital financing (Chahine et al., 2019). As it is claimed, constructing a pleasing reputation is strategic to handling stakeholders' impressions, investment in a worthy corporate reputation may strengthen an organisation's competitive advantage and hence capitalise on stockholders' wealth. Therefore, it is observed that when managers manipulate earnings at the same time, they behave in a very responsible manner to the diverse stakeholders that they are performing to assure wealth maximisation. Otherwise, firms with a low level of CSR initiatives are less likely to be involved in EM practices. Hence, agency theory provides insights into managerial purposes and behaviours by suggesting that bank managers who engage in CSR activities to optimoise own interests are also involved in EM practices.

\section{Literature Review and Hypotheses Development}

The studies related to CSR and firm financial performance is are ample but the literature regarding CSR disclosure and EM is insufficient, and the research outcomes are mixed. Research (Prior et al., 2008; Grougioua et al., 2014) that investigated the relationship between quality of financial reporting and CSR mainly addressed the opportunistic application of CSR within the scope of agency theoretical background. Notwithstanding pursuit of the interests of the organisation's stakeholders, it has been claimed that executives may participate in CSR actions to fulfil their interests or for the tenacity of camouflaging the consequences of misconduct in the business's undertakings (Chahine et al., 2019; Carroll, 1979). It has also been argued that to accomplish their career goals, CSR may be utilised as a window-dressing mechanism by managers (Muttakin et al., 2015). Likewise, based on agency theory (Grougiou et al., 2014) and (Kim et al., 2012) suggested a managerial opportunism perspective of CSR in which managers engage in CSR initiatives to develop their careers or other personal interests.

This study found limited studies examined the relation between CSR disclosure and EM and the results are mixed. Transparent financial reporting directs that information is more relevant to the stakeholders to make investment decisions (Gras-Gil et al., 2016). In this regard, CSR initiatives are associated with quality earnings and the primary intention of the organisation is to meet the demands of the diverse stakeholders (Amar et al., 2018). The previous study claims that socially accountable businesses are focused on developing enduring affiliations with stakeholders (longstanding viewpoint) rather than on increasing existing profits for maximising short-term benefits (Chih 
et al., 2008). The business has to purposefully apply its consideration to fulfil the demands of the stakeholders as the stakeholders' control possessions that are essential for the existence and continued success of the organisation (Choi et al., 2013). In line with this opinion, preceding literature reveals that organisations that are involved less in earnings management are more devoted to CSR commitment and its disclosure (Hong \& Andersen, 2011; Suyuno et al.,2018).

Therefore, empirically, the above studies found that CSR initiatives and it's the disclosure is are negatively related to EM, and recommend that companies with a robust longstanding obligation to CSR are less probable to participate in EM practice through maintaining clarity in economic recording. Thus, this study expects an adverse relation between CSRR and EM in the perspective of transparent financial reporting. These studies (Chih et al., 2008, Hong \& Andersen, 2011; Choi et al., 2013; Suyuno et al., 2018) are consistant with the perspective of the stakeholder theory.

Thus, this study aims to investigate the relationship between CSR reporting and EM in the overall banking sector of Bangladesh. Following the above conflicting remarks based on transparent financial reporting perspectives, the following hypothesis is formulated:

$H_{1 a}:$ There is a negative (transparent financial reporting perspective) relationship between CSR reporting and EM in the banking sector of Bangladesh.

On the other hand, some researchers conjectured a different interpretation and recommended that to disguise the opportunistic conduct, managers use CSR as their entrenchment strategy (the management opportunism standpoint) (Choi et al., 2013). Several motivations for CSR such as reputation, moral responsibility, and financial performance expect an adverse relationship, whereas some research are reliant on the opportunistic application of CSR and advocate a positive relation between CSR and EM (Kim et al., 2012). Furthermore, prior studies have advocated that to camouflage professional opportunistic motives (under opportunism hypothesis) managers may use CSR as a strategic weapon. Managers may escape inspection from stakeholders through CSR undertakings that protect their job (Prior et al., 2008). Moreover, a healthy relationship with stakeholders can be used as a defensive tool against aggressive buyouts (Suyono \& Farooque, 2018). Hence, managers who are involved in earnings manipulations may be motivated by extensive CSR activities to shed their entrenchment mechanisms (Prior et al., 2008). But, empirical results concerning the positive stimulus of CSRR on EM or financial reporting quality (FRQ) remain inconclusive (Chih et al., 2008; Kim et al., 2013). These studies (Prior et al., 2008, Choi et al., 2013, Kim et al., 2012) are consistant with the perspective of the agency theory.

Following the above conflicting remarks based on transparent financial reporting and opportunistic financial reporting perspectives, the following hypothesis is formulated:

$H_{1 b}$ : There is a positive (opportunistic perspective) relationship between CSR reporting and EM in the banking sector of Bangladesh.

On the other hand, the conventional and Islamic financial system is different, and the pillar of Islamic economic structure is Shariah principles, in which the primary objectives do not include the capitalising of shareholders' wealth, but incorporate both earnings and communal accountability simultaneously (Alsaadi et al., 2013). Islamic economic system incorporates fiscal and legal traits along with social, spiritual and ethical aspects in terms of principles and philosophy of Islamic religion, which is relevant to (Carroll, 1979) model consistent with the economic, ethical, discretionary and legal classifications (Elnahass et al., 2014). It is crucial to know that Islamic business bodies exist not only for the wellbeing of benevolent associations, but financially function at an operational and competent mean (Alsaadi et al., 2013). However, for maximise stakeholders' wealth, they must also not disregard other moral and social commitments (Mersni et al., 2015) and try to keep the proper balance between 
returns and social aims and other benefits to their diverse stakeholders concerning Islamic Shariah ideologies (Zainuldin et al., 2018). In the case of disclosure, Shariah-compliant banks disclose relatively more CSR information than conventional counterparts (Belal et al., 2015; Shobhani et al., 2012).

In terms of transparency, Shariah principles assert that business activities should be carried out in a transparent manner such that every aspect of these activities is clarified to various parties based on the guidelines of the shariah supervisory board (SSB) (Alsaadi et al., 2013). In the Islamic point of view, managerial discretion in terms of manipulating the contracting settlements such as EM is strictly prohibited (Ibrahim et al., 2015) and Shariah Supervisory Board imposes guidelines based on Shariah principles to restrict unethical motives. Also, Khan and Akter (2001) stated that to alleviate professional opportunisms and lessen managerial enticements of controlling monetary recording, moral, ethical codes, for instance, honesty, integrity, and faithfulness action as per watching instrument and it is mandatory to follow the guidelines of the SSB . Additionally, it is mandatory to the Shariah-compliant banks to follow the guidelines of the Shariah principles which is are supervised by the SSB.

The above argument comply with the stakeholder salience theory. Overall, the theory considers firms as part of a broader social system, within which they exist. Furthermore, a firm is influenced by and, in turn, influences the society with different stakeholders group.This study focused on SSB that provides assurance on Shariah based legitimacy, in which it operates (Alsaadi et al., 2013) and in this way Islamic banks comply with Shariah regulations. This Shariah complianace ultimately satisfies the powerful stakeholders such as the Central Bank, the National Tax Authority, etc. Thus, according to the stakeholder seliance theory, CSR disclosures can be construed as a mechanism for ensuring commitment to the social contract.

Therefore, the above statements indicate that Shariah ethical codes influence the relationship between socially responsible investment and transparent financial reporting. In other words, as a consequence of Shariah standards, it is possible to reduce earnings manipulation and to enhance ethical authoritative rather than opportunistic actions as an enticement of CSR enactment (Tafti et al., 2012). In the perspective of Bangladesh, the Islamic banks generate more profits and also involved in superior CSR activitives than conventional banks (Belal et al., 2015). Thus, one of the foremost purposes of this study is to investigate whether CSR oriented Shariah-compliant banks are more likely to engage in providing transparent financial reporting. Hence, this study expects that corporations that deal with Islamic banking services and are seen to have incorporated the Shariah ethics would be more focused on the quality of their financial reporting along with greater participation in societal obligation through complying SSB guidelines based on stakeholder-saliance theory. Therefore, this research hypothesises that:

$\mathrm{H}_{2}$ : Shariah principles moderate the relationship between CSR reporting and Earnings Management in the banking sector of Bangladesh.

Multiple sources inspired this study's decision to centre its examination on the banking sector. First, it is evident that banks make superior CSR commitments every year (Ullah et al., 2015). However, prior studies have suggested that it is vital to examine whether the endeavours made by banks to fulfil their CSR promises are appreciated (Carnevale et al., 2014; Ullah et al., 2015; Islam \& Kokubu, 2017). Second, although various regulatory authorities have established frameworks and strategies for sustainability disclosure in the financial sector, such as Global Reporting Initiatives (GRI), very little focus has been given to examining the nature and extent of CSR disclosure based on international guidelines, particularly in the developing country banking sectors. Third, a few authors contend that financial firms (banks) are more inclined to manipulate their earnings than non-financial related associations (Grougiou et al., 2014; Chahine et al., 2019). Consequently, 
it is essential to investigate the opportunistic motives of the bank managers.

Overall, from the above discussion, the relationship between CSR reporting and EM are mixed. Given differences in outcomes and the significance of this relationship for scholastics and market members, further investigation is required. Besides, most of the studies have been done in the developed country context. Therefore, it is essential to investigate whether CSR related disclosures by firms are based on an original plan (long-term value maximisation) or are only intended to deceive stakeholders (opportunistic viewpoint) from the context of Bangladeshi banking sector. However, the present research did not find any study that discussed the relationship between CSR reporting and earnings management in the overall banking sector. Moreover, due to the scarce empirical literature on the salience of the stakeholders, this study investigated the primary motives of the managers for disclosing CSR information and the link with these social initiatives with earnings management. Consequently, this study also examined the moderating effect of shariah principles in this association and extend the

prior literarure through incorporating the impact of stakeholder-saliance theory.

\section{Methodology}

\section{Sample Data}

This study examined the relationship between CSR reporting and EM. This relationship was tested using quantitative research design. This study was carried out in listed banking companies (conventional and Islamic banks) on the Dhaka Stock Exchange (DSE). To gather information based on the research questions, this study limited its investigation to 2017 because this was the most recent year of annual reports available when the analysis began. This study collected annual reports from the DSE library from 2009 to 2017. The starting period of 2009 was chosen because in 2008 the central bank of Bangladesh began to publish CSR reviews for listed commercial banks, which was followed by significant increase in voluntary CSR disclosure.
Therefore, the data for this study encompassed 270 firm-year observations from 2009 to 2017.

\section{Empirical Models}

The primary objective of this research is evaluating the connection between earnings management (proxied by discretionary accruals) and CSR reporting (measured by CSR disclosure index). Thus, subsequent multiple regression is engaged to assess the affiliation between earnings management proxy as outcome variables and CSR reporting as a predictor variable. The second objective of this study is to assess the relationship between earnings management and CSR reporting in the Islamic banking sector. This study introduces SHARIAH as an independent variable to differentiate its impact from conventional banking counterpart in the association of earnings management (as dependent variable) and CSR reporting (as an independent variable). Additionally, firm size, market to book value, leverage, ROA, LEV and TLAGACC are considered as control variables related to the research hypotheses. The following prototypes are used to test our hypotheses.

$$
\begin{aligned}
& E M=\beta_{0}+\beta \underset{1}{C S R R}+{ }_{i t} \beta F S_{2} I Z E+\beta M B_{3}+\beta \\
& R O A+\beta_{5} L E V+\boldsymbol{\beta}_{6} T L A G A C C+\beta_{5} A Q+\varepsilon_{i t}
\end{aligned}
$$

(Model 1)

$$
\begin{aligned}
& E M=\beta_{0}+\beta_{1} C S R R_{i t}+\beta_{2} S H A R I A H+\beta_{3} C S R R \\
& \times S H A R I A H+\beta_{4} F S I Z E+\beta_{5} M B+\beta_{6} R O A+ \\
& \beta_{7} L E V++\boldsymbol{\beta}_{8} \text { TLAGACC }+\beta_{9} A Q+\varepsilon_{i t}
\end{aligned}
$$

(Model 2)

\section{Independent Variable - Corporate Social Responsibility Reporting Indices}

To construct an inclusive magnitude of a bank's commitment to sustainability or CSR reporting, this study considers these issue areas to be more relevant to banks in terms of financial Service Sector (FSS) of GRI and extensive review of prior studies for developing the ten major aspects of CSRR issue areas, namely: product and service responsibility, energy consumption and savings, natural environmental issues, community investment, employee development, economic issues, human rights, education, health and Islamic commitment. Following Ullah and 
Table 1: Variables definition

\begin{tabular}{lll}
\hline EM & $=\begin{array}{l}\text { Earnings management (Proxied by earnings management is the } \\
\text { scale of discretionary accruals); }\end{array}$ \\
\hline CSRR & $\begin{array}{l}\text { CSR reporting score/ index over the fiscal year (the CSR } \\
\text { disclosures provided in the annual report); }\end{array}$ \\
\hline Control Variables: & $=$ & The ratio of total debt to the total value of assets; \\
\hline Leverage (LEV) & $=$ & Natural logarithm of total assets; \\
\hline Firm Size (SIZE) & $=$ & The ratio of the market value of firm equity \& book value of firm \\
Market to Book Value of Equity & equity \\
(MB) & $=\begin{array}{l}\text { Company's annual net profit from operations after tax, divided by } \\
\text { the book value of total assets; }\end{array}$ \\
\hline Return on Assets (ROA) & $=$ One year Lag total accruals; \\
\hline TLAGACC & $=$ Coded as 1 if firms audited by Big-4 affiliated firms, 0 otherwise; \\
\hline AQ & $=$ & 1 for Islamic Banks, 0 otherwise; \\
\hline Shariah Principles (SHARIAH) & $=$ & The interaction effect between CSRR \& Shariah principles \\
\hline CSRR $\times$ SHARIAH & $=$ & An error term \\
\hline$\varepsilon_{\text {it }}$ &
\end{tabular}

Rahman (2015) and Muttakin and Khan (2014) the CSRR index is calculated in equation (1) as follows:

$$
\operatorname{CSRR}=\sum_{\mathrm{i}=1}^{\mathrm{n}} \mathrm{di}
$$

Where,

$\mathrm{d}_{\mathrm{i}}=1$ if the item di is reported;

$\mathrm{d}_{\mathrm{i}}=0$ if the item is not reported; and

$\mathrm{n}=$ number of items.

To assess the reliability of CSR reporting index, reliable with previous revelation index researches (Khan et al., 2009; Muttakin et al., 2015; Belal et al., 2015), this study will apply the Cronbach's coefficient alpha (Cronbach, 1951) to measure the internal consistency and reliability of the CSRR index (Muttakin et al., 2015; Belal et al., 2015). The coefficient alpha for the nine unlike information groups under three board classifications of disclosure index is expected to be more than 0.70. This measurement delivers good backing in the condition where the set of selected items in the disclosure index captures the same fundamental construct (Muttakin et al., 2015). This CSR reporting index is shown in Appendix A.

\section{Dependent Variable - Earnings Management}

In this thesis, the first measure of EM is the discretionary accruals which are assessed from the (Jones, 1991) model as adapted by (Yasuda et al., 2004) for banking organisations. This study runs the subsequent regression in an attempt to get the discretionary part of the bank's total accruals:

$A C C R_{t}=\beta_{1}\left(1 /\left(T A_{t--}\right)+\beta_{2}\left(\Delta O I_{t} / T A_{t-1}\right)\right.$

$+\beta_{3}\left(B R E_{t} / T A_{t-1}\right)+\varepsilon_{i t}$

where,

ACCR $=$ Total accruals assessed as the variance between net incomes and operating cash flows;

TA = Total assets;

$\Delta \mathrm{OI}=$ Variation in the bank's revenue from operation between $\mathrm{t}-1$ to $\mathrm{t}$;

BRE = Bank's premises and equipment; $\varepsilon_{i t} \quad=$ An error term.

All variables and the intercept are scaled with lagged total assets that help to reduce the heteroscedasticity effect (Rahman et al., 2018). In Equation (2), the residuals are indicated as the discretionary part of total accruals which is reliant on executive discretion and is our key variable of interest. 


\section{Results and Discussion}

Table 2 shows the descriptive statistics for mean, standard deviation, median, maximum, minimum, kurtosis, and skewness for DACC, CSRR, and related control variables. The results of the descriptive statistics are shown below.

The mean value for CSRR was 0.479 (median 0.470). The descriptive statistic result demonstrate that CSRR had a mean value of $47.90 \%$ on a scale between 0 and 84 because the disclosure-index contained 42 items. This result can be linked to Ullah et al., 2015, who used Bangladeshi cross-sectional data from banking companies to discover a mean CSRR value of 0.4597. In comparison to this study, disclosure level increased from $45.97 \%$ to $48.31 \%$. Similarly, (Muttakin et al., 2015) reported a mean (median) CSRR of 0.2230 (0.200) for 135 non-financial organisations from 2005 to 2009 , suggesting that financial organisations disclose more CSR information than non-financial organisations. For the dependent variable, the mean value of DACC was $0.002(0.000)$. Previous related studies similar to this study outcomes are (Kim et al., 2012) (mean DACC $=0.005$ ) and (Prior et al., 2008) (mean DACC $=0.004)$. Similarly, Bangladesh and (Muttakin et al., 2015) stated a mean (median) DACC of 0.119 (0.063), suggesting that DACC was higher in the non-financial sector than in the financial sector.

For the control variable, this study used FSIZE (the natural log of total assets) as a proxy for firm size. The mean (median) value of FSIZE was 23.335 (23.335) with a standard deviation of 0.674 . The mean (median) value of ROA was 0.009 (0.010). The result shows that mean ROA was positive and that the listed banks were profitable. The mean (median) for TLAGACC was 0.173 (0.006). The mean (median) value of MB was 2.936 (2.266), showing that book value equity was lower than its market value, indicating growth opportunities. AQ was dichotomous variables. The mean (median) value of AQ was $0.381(0.000)$, indicating that $38.1 \%$ of firms were audited by BIG-4 affiliated audit firms. Besides, the mean (median) value of LEV was 0.935 (0.913), indicating a tendency to generate funds through equity capital rather than external financing or debts.

Table 3 reports the correlation coefficients among the regressors. It can be seen that the highest percentage of correlations between ROA and SHARIAH $(r=0.641)$. Table 3 shows that the Variance Inflation Factors (VIFs) for all correlated variables did not exceed 10, which

Table 2: Descriptive statistics $(N=270)$

\begin{tabular}{lrrrrrrr} 
Variables & Mean & Median & $\begin{array}{c}\text { Standard } \\
\text { Deviation }\end{array}$ & Minimum & Maximum & Skewness & Kurtosis \\
\hline CSRR & 0.479 & 0.470 & 0.105 & 0.216 & 0.674 & -0.182 & 0.534 \\
\hline$D A C C$ & 0.002 & 0.000 & 0.012 & -0.027 & 0.039 & 0.644 & 0.210 \\
\hline$A Q$ & 0.381 & 0.000 & 0.486 & 0.000 & 0.100 & 0.491 & 1.772 \\
\hline SHARIAH & 0.233 & 0.000 & 0.423 & 0.000 & 0.100 & 1.268 & 0.395 \\
\hline$M B$ & 2.936 & 2.266 & 2.350 & 0.450 & 16.130 & 0.429 & 0.196 \\
\hline LEV & 0.935 & 0.913 & 0.143 & 0.470 & 1.766 & 1.779 & 1.783 \\
\hline FSIZE & 23.335 & 23.335 & 0.674 & 21.510 & 25.150 & 0.024 & 0.183 \\
\hline ROA & 0.009 & 0.010 & 0.013 & -0.031 & 0.041 & -0.048 & 0.123 \\
\hline TLAGACC & 0.173 & 0.006 & 2.312 & 3.583 & 30.327 & -0.002 & 0.216 \\
\hline
\end{tabular}

Notes: $C S R R=$ corporate social responsibility reporting; $A F=$ the natural $\log$ of audit fees; $L E V=$ the ratio of debts to total assets; $F S I Z E=$ the natural logarithm of total assets; $D A C C=$ discretionary accruals; $A Q=$ coded as 1 if the firm audited by Big 4 affiliated firm in the financial year, 0 otherwise; SHARIAH = as measure of Shariah principles that coded as 1 if the firm is Shariah-compliant, 0 otherwise; $M B=$ market to book value ratio; $R O A=$ return on assets; $T L A G A C C=$ the lagged total accruals 
Table 3: Pairwise correlation matrix (N=270) for CSRR-EM (DACC) Models

\begin{tabular}{|c|c|c|c|c|c|c|c|c|c|c|c|c|}
\hline \multicolumn{13}{|c|}{ Correlations } \\
\hline & & 1 & 2 & 3 & 4 & 5 & 6 & 7 & 8 & 9 & 10 & 11 \\
\hline 1 & DAAC & 1 & .47 & .03 & -.22 & -.12 & -.27 & .20 & -.09 & -.27 & -.18 & -.19 \\
\hline 2 & DAAC $_{t-1}$ & & 1 & .05 & -.13 & -.10 & -.07 & .24 & -.08 & -.32 & -.17 & -.17 \\
\hline 3 & CSRR & & & 1 & .18 & .02 & . 10 & -.01 & -.10 & .13 & .01 & .20 \\
\hline 4 & FSIZE & & & & 1 & .36 & .26 & -.04 & .13 & .23 & .06 & .01 \\
\hline 5 & ROA & & & & & 1 & .08 & -.00 & -.03 & .28 & .64 & .03 \\
\hline 6 & $\mathbf{A Q}$ & & & & & & 1 & -.15 & -.07 & .246 & .10 & .119 \\
\hline 7 & LEV & & & & & & & 1 & -.43 & -.05 & -.29 & -.04 \\
\hline 8 & TLAGACC & & & & & & & & 1 & -.03 & -.05 & -.06 \\
\hline 9 & MB & & & & & & & & & 1 & -.19 & -.14 \\
\hline 10 & SHARIAH & & & & & & & & & & 1 & .60 \\
\hline 11 & CSSR*SHARIAH & & & & & & & & & & & 1 \\
\hline
\end{tabular}

Notes: The table shows Pearson correlation coefficients among the main variables involved in the analysis.

Variables are defined in Table 1.

is the cut-off point recommended (Hair et al., 2006). Therefore, there were no multicollinearity issues in this study. The study of Gujarati and Porter (2008) stated that when a correlation between an independent variable is less than 0.80 then it is acceptable. This study did not find any correlations between independent variables that exceed the 0.80 limit, which shows an absence of multicollinearity problems.

This study develops outcomes from the GMM estimation along with cross-section fixed effect estimation. The fixed effect specification for balanced panel observations is supported by the Breusch-Godfrey (Breusch, 1978; Godfrey, 1978) Lagrange Multiplier test (LM test), which rejects the null hypothesis that errors are independent within banks. A White test (White, 1980) is also applied to examine crosssectional heteroskedasticity, and the null hypothesis of homoscedasticity is rejected at $5 \%$ level of significance. For this reason, we did not run regression through ordinary least square (OLS) estimations and used GMM estimator in the regreesion analysis.

Consistent with (Arellano et al., 1991, Arellano et al., 1995 and Blundell et al., 2000), this study used the two-step dynamic panel data approach. This technique was also applied to GMM estimations to address probable heteroskedasticity, serial correlation, and endogeneity issues within variables (Rahman, et al., 2017). One-step and two-step estimators used linear GMM techniques. As shown in previous literature, the two-step estimator is more accurate than the one-step estimator (Moudud-Ul-Huq, S., 2019). Moreover, dynamic panel models have difference panel estimators and system panel estimators. According to prior research, the probable cause for omitted variable bias can be removed through the difference panel estimator and the system panel model estimator pools differences within regression levels to reduce inaccuracy and biases related to difference estimators (Rahman et al., 2017).

The dynamic panel estimation method or GMM model is mainly used on small macro groups with endogenous variables (Rahman et al., 2018). In line with previous literature, endogeneity problems may arise due to causal relationships between dependent and predictor variables. In this situation, dynamic panel GMM minimises omitted variable bias and inconsistencies due to endogeneity issues (Yip et al., 2011). This study also used the Durbin-WuHausmann test to address endogeneity issues. The Sargan statistic was employed to investigate 
instrumental variable over-identification in all models.

Table 4 shows the combined results for the relationship between CSRR and EM as well as the moderating role of SHARIAH on this relationship. This study used simultaneous equation modeling to rationalise this topic. This study treated CSRR and ROA (a measure of firm performance) as endogenous for discretionary accruals, including their lag (one period) values alongside predictor variable lag (one period).

For all three models (1-2) the lagged dependent variable showed significant results, suggesting that a high degree of discretionary accrual persistence and the existence of model auto-correlations. This study found positive lagged association coefficients. These outcomes support previous studies (Cho \& Chun, 2015).

The coefficients of $C S R R$ were significant and positive across all three models (1-2). The coefficients of CSRR were as follows: Model $1(\mathrm{~b}=0.271, \mathrm{p}<.05)$; and Model $2(\mathrm{~b}=0.568$, $\mathrm{p}<.05)$. These results support the opportunistic perspective hypothesis $\left(\mathrm{H}_{1 \mathrm{a}}\right)$, suggesting that managers in banks that practised CSR disclosure used earnings manipulation through discretionary accruals to fulfill their own agendas. These findings are in line with the previous literature (Prior et al., 2008; Grougiou et al., 2014; Muttakin et al., 2015).

In Model 2, the coefficient for Shariah principles (SHARIAH) showed negative and significant results, indicating that Shariah principles prevented firms from using earnings manipulation, ensuring superior report quality. This outcome supports previous research (Ibrahim et al., 2015; Z ainuldin et al., 2018). For the interaction term, CSRR*SHARIAH $(b=.485, p<.05)$, showed significant negative association with earnings management. This supports research hypothesis $\mathrm{H}_{2}$. This result suggests that Shariah-compliant CSR firms do not manipulate their earnings for shortterm benefits and had higher quality reports as Shariah principles do not permit unethical reporting practices (Zainuldin et al., 2018) and encourages voluntary social and ecological initiatives (Hassan et al., 2015).

The Model 1 control variables MB and FSIZE were statistically significant. FSIZE was significant at the 0.01 level with a negative coefficient, suggesting an interrelationship between FSIZE and EM practices. MB was significant at the 0.01 level, with an expected negative sign. AQ, TLAGACC, and ROA showed a significant negative relationship with EM LEV showed a significant positive relationship with EM indicating managers in highly leveraged firms have incentives to manipulate earnings through discretionary accruals.

For Model 2 AQ (coefficient $=-4.024$, $\mathrm{p}$-value $<0.05$ ), ROA (coefficient $=-0.589$, $\mathrm{p}$ value $<0.05$ ), FSIZE (coefficient $=-3.249$, $\mathrm{p}$ value $<0.01$ ), and TLAGACC (coefficient $=-0.683$, p-value $<0.01)$ were positively and significantly correlated with EM. MB (coefficient $=-6.544$, p-value $<0.01)$ and LEV (coefficient $=0.419$, p-value $<0.01$ ) showed negative and positive coefficients, respectively. AUDC found insignificant results across all three models (1-2) which indicate that AUDC did not influence EM

This study considered CSRR and ROA as endogenous to discretionary accruals and employed a lag (one period) for these two variables as well as the dependent variable as instruments. Diagnostic tests concerning the dynamic panel GMM approach shows consistent results that satisfied the underlying assumptions of these econometric models. Specifically, AR (1) and AR (2) measured first and second-order serial correlation in the residuals, respectively. A significant outcome for AR (1) indicates the existence of first-order serial correlation in the residuals, while an insignificant result of AR (2) indicates the non-existence of secondorder serial correlation in the residuals. The insignificant result of the Sargan test for overidentifying restrictions indicates that the instruments were exogenous. 
The number of instruments varied between 17 to 18 for all models (1-2). The number of instruments increased to 25 to 27 after considering year dummies, which was not greater than the number of banks (30). This confirmed that the study findings were not biased by instruments proliferation. The LM test for serial correlation and White test for heteroscedasticity also proved the existence of such issues in the model. The null of white and LM tests show that there is no heteroscedasticity and serial correlation issues in a research model, but this study rejects the null hypothesis. For this reason, this study employed the two-step system GMM estimator to confirm outcome reliability. Also, this study performed a Hausman fixed/random effect test and rejected the null hypothesis, confirming that the fixed effect model was appropriate. Finally, the analysis of non-stationaries by the Augmented Dickey Fuller-Fisher test were performed for each variable (Appendix B).

The results of the study confirm that opportunistic perspectives $\left(\mathrm{H}_{1 \mathrm{a}}\right)$ are positively related to the relationship between CSR reporting and EM practices. These results confirmed that Bangladeshi bank managers may use their earnings management practices through discretionary accruals (DACC) to deceive stakeholders and enhance their reputational capital.

There are multiple possible reasons for these results. Due to the financial scam in 2008, insecurity and disbelief rise among the market participants and shareholders (Grougiou et al., 2014). To recover this reputational loss and faith, organisations commonly adopt voluntary initiatives in terms of CSR activities (Chahine $e t$ al., 2019). On the other hand, there is a significant mistrust regarding these types of actions. Prior findings have observed the utilisation of the CSR as an eye washing tool by the managers (Yip et al., 2011; Muttakin et al., 2015). They may use their discretionary choices to deceive stakeholders and uphold their personal gain. Consistent with stakeholder theory, such unethical practices generate hidden forces to the credibility of a bank and consequently effects adversely in the capital market. Therefore, to escape such adverse situation, managers try to fulfill stakeholders' interests in two different ways. First, to uphold their positions from the activist group of stakeholders as a result of earnings manipulation, managers attempt to satisfy stakeholders' interests through extensive CSR initiatives. Second, managers tend to get together with other stakeholders as a hedging strategy against penalising actions from stockholders affected adversely by these EM practices. Findings of the study revealed that high CSR disclosure Bangladeshi banks more likely to manipulate their earnings in terms of discretionary accruals. These results are consistent with the previous studies which proved that the positive association between CSR reporting and earnings management practices (Prior et al., 2008; Muttakin et al., 2015; Chahine et al., 2019) and Shariah ethical issues retrain managers to deceive stakeholders through earnings management from the perspective of stakeholder salience theory. Overall, the results of our analysis of the banking sector in Bangladesh are therefore consistent with the notion that maintaining a high level of CSR activities is an opportunistic motive to meet the demand of the manager's own incentives (such as share of profit, bonus) that champions such social causes, regardless of how legitimate the claims of stakeholders benefiting from a CSR agenda might be from the point of agency theory. However, the stakeholder salience theory considers firms as part of a broader social system, within which they exist. Furthermore, a firm is influenced by and, in turn, influences the society with different stakeholders' group in which it operates such as shareholder, regulatory authority (Central bank) (Alsaadi et al., 2013; Ullah et al., 2015; Thijssens et al., 2015; Neill et al., 2005) and maintaining the legitimacy of the Shariahcompliant issues (SSB for shariah legitimacy) restrain from the earnings management practices. Thus, according to the above theory, CSR disclosures, can be construed as a mechanism for ensuring commitment to the social contract when Shariah principles is are a major concern. 
Table 4: The result of GMM estimations

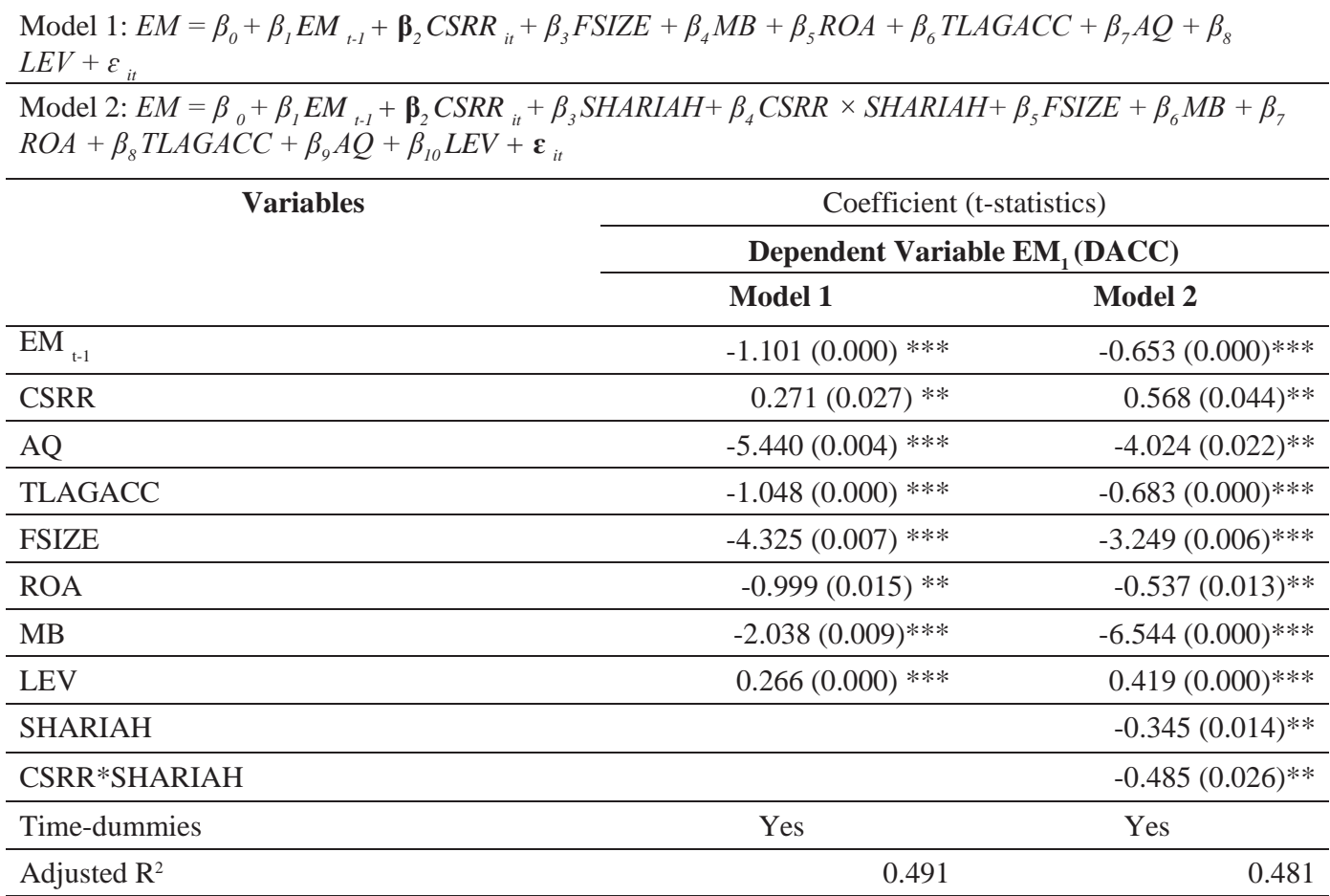

\begin{tabular}{lrr}
\hline \multicolumn{2}{c}{ Diagnostic tests } & \\
\hline $\operatorname{AR}(1)$ & $-3.12(0.002)$ & $-3.59(0.000)$ \\
\hline $\operatorname{AR}(2)$ & $0.10(0.923)$ & $0.66(0.512)$ \\
\hline Sargan test $(p$-value)/Hansen test & 0.153 & 0.344 \\
\hline No. of instruments & 25 & 27 \\
\hline
\end{tabular}

\section{Econometric tests}

\begin{tabular}{lrr}
\hline Hausman F/R test $(p$-value) & 0.000 & 1.000 \\
\hline Endogeneity test $(p$-value $)$ & 0.020 & 0.005 \\
\hline White test $(p$-value) & 0.000 & 0.000 \\
\hline LM serial auto correlation test (p-value) & 0.000 & 0.000 \\
\hline Obs. (Banks) & 270 & 270 \\
\hline No. of Banks & 30 & 30 \\
\hline
\end{tabular}

Notes: Dependent variable is EM (DACC). Sargan test confirms that instruments used are not over-identifed and not correlated with the residuals. The null hypothesis of the serial correlation, heteroscedasticity and endogeneity tests are rejected that indicate the existance of these issues. AR ( 1 and 2) confirm the second order serial auto-correlation. The null hypothesis of the fixed/random test approves that fixed effect estimation is appropriate. Detailed definitions of all variables are given in Table $1 . *, * *$ and $* * *$ indicate significance at the $10 \%, 5 \%$ and $1 \%$ levels, respectively.

Source: Author's calculation 
Thus, managers may be influenced by own interests or in pressure to fulfil the demand of the diverse stakeholder groups but Shariah legitimacy influences to perform business activities ethically. Therefore, the study results adhere to the stakeholder salience theory that demonstrates Banngladeshi Shariah- compliant banks not only undertake CSR activities to fulfil the requirements of the different stakeholders (Central Bank of Bangladesh, Tax authority, Ordinary shareholders) but also uphold the Shariah principles by satisfying the legitimate requirements of the SSB.

\section{Robustness and Sensitivity Analysis}

This study performed supplementary analyses to investigate the robustness of the research outcomes. Robustness checks verify core research findings using different methods, such as altering a dependent variable with a substitute measurement, changing the regression analysis methods, and adding alternatives control variables. This study used 2 SLS techniques in place of GMM estimations to check outcome effectiveness. This study also performed numerous sensitivity analyses. The study investigated two models (1-2) using 2 SLS. The outcomes of the 2SLS estimators are presented in Table 5.

For the Discretionary Accruals Structure (DACC) for Model (1-2), CSRR showed a significant and positive association with EM (proxied by DACC), indicating that managers might use CSR initiatives as an opportunistic tool to shed the negative consequences of EM practices. Therefore, for models (1-2) the opportunistic perspective hypothesis $\left(\mathrm{H}_{1 \mathrm{a}}\right)$ was suitable and the regression coefficient for CSRR-EM were $($ coefficient $=0.689, \mathrm{p}<.01)$ for Model 1, and (coefficient $=0.394, \mathrm{p}<.01$ ) for Model 2. These results are in line with previous literature (Prior et al., 2008; Grougiou et al., 2014; Muttakin et al., 2015). Moreover, the lagged dependent variable $\mathrm{EM}_{\mathrm{t}-1}\left(\mathrm{DACC}_{\mathrm{t}-1}\right)$ was statistically significant across all models (1-2).

Model 2 also showed the moderating effect of CSRR *SHARIAH on the association between
CSRR and EM (DACC). The coefficients of the interaction variables for Model 2 was (coefficient $=-0.001, \mathrm{p}<.05$ ). These outcomes support hypothesis $\mathrm{H}_{1 \mathrm{a}}$ and $\mathrm{H}_{2}$. The findings were similar irrespective of the regression techniques employed in this study. The interaction term (moderating variable) demonstrated substantial statistical significance. The coefficient of the interaction variable (CSRR*SHARIAH) has a negative value in Model 2, indicating that Shariah-compliant firms that perform superior CSR activities do not deceive shareholders through earnings manipulation for temporary gains and also present an accurate financial position to stakeholders. Shariah principles do not contain contradictory mechanisms such as discretionary practices in financial reporting (Zainuldin et al., 2018). Shariah principles also instigate communal initiatives (Ibrahim et al., 2015).

For the control variables, in Model 1 LEV was statistically significant with the expected positive sign. ROA and FSIZE were significant at a 0.01 and 0.05 significance level, respectively, with a negative coefficient, suggesting firms that have large FSIZE generate more operating revenue and are less likely to use EM practices. $\mathrm{AQ}$ and $\mathrm{MB}$ were significant at the 0.05 significance level, with the expected negative sign. TLAGACC was significant at a 0.05 significance level with a negative coefficient, which is consistent with (Muttakin et al., 2015).

Model 2 showed similar results with an TLAGACC (coefficient $=-0.157$, p-value $<$ 0.05 ) and $\mathrm{MB}$ (coefficient $=-4.112$, p-value < $0.10)$ that were statistically significant with the expected negative sign. AQ (coefficient $=-0.537$, p-value $<0.01)$, ROA $($ coefficient $=$ 0.846, p-value $<0.01$ ), FSIZE (coefficient $=$ -2.983, p-value < 0.05), and OCF (coefficient $=0.222, \mathrm{p}$-value $<0.05$ ) showed a significant negative coefficient with EM. LEV showed significant positive association with EM.

For models (1-2), this study employed the Hausman endogeneity test to justify 2SLS estimation validity. The outcomes of the endogeneity test rejected the null hypothesis and 
supported the presence of endogeneity in the research models. For this reason, this study used 2SLS to confirm the robustness of the GMM estimations. The Sargan test was also employed to examine the over-identification of instrumental variables and found that instrumental variables were adequately specified in all models.

Table 5: The result of 2SLS estimations

Model 1: $E M=\beta_{0}+\beta_{1} E M_{t-1}+\boldsymbol{\beta}_{2} C S R R_{i t}+\beta_{3} F S I Z E+\beta_{4} M B+\beta_{5} R O A+\beta_{6} T L A G A C C+\beta_{7} A Q+\beta_{8}$ $L E V+\varepsilon_{i t}$

Model 2: $E M=\beta_{0}+\beta_{1} E M_{t-1}+\boldsymbol{\beta}_{2}$ CSRR ${ }_{i t}+\beta_{3}$ SHARIAH $\beta_{4}$ CSRR $\times$ SHARIAH $\beta_{5}$ FSIZE $+\beta_{6} M B+\beta_{7}$ $R O A+\beta_{8} T L A G A C C+\beta_{9} A Q+\beta_{10} L E V+\varepsilon_{i t}$

\begin{tabular}{|c|c|c|}
\hline \multirow[t]{3}{*}{ Variables } & \multicolumn{2}{|c|}{ Coefficient (t-statistics) } \\
\hline & \multicolumn{2}{|c|}{ Dependent Variable (DACC) } \\
\hline & Model 1 & Model 2 \\
\hline Intercept & $0.652(0.033)^{* *}$ & $0.752(0.022)^{* *}$ \\
\hline $\mathrm{EM}_{\mathrm{t}-1}\left(\mathrm{DACC}_{\mathrm{t}-1}\right)$ & $0.191(0.043)^{* *}$ & $0.155(0.034)^{* *}$ \\
\hline CSRR & $0.689(0.005) * * *$ & $0.394(0.003)^{* * * *}$ \\
\hline AQ (Dummy) & $-0.671(0.031)^{* *}$ & $-0.537(0.007)^{* *}$ \\
\hline TLAGACC & $-0.243(0.022) * *$ & $-0.157(0.017)^{* *}$ \\
\hline FSIZE & $-3.616(0.019) * *$ & $-2.983(0.032) * *$ \\
\hline ROA & $-0.295(0.010) * *$ & $-0.846(0.005)^{* * *}$ \\
\hline MB & $-1.647(0.049) * *$ & $-4.612(0.014)^{* *}$ \\
\hline LEV & $0.349(0.000)^{* * *}$ & $0.409(0.000)^{* * *}$ \\
\hline SHARIAH (Dummy) & & $-0.471(0.044)^{* *}$ \\
\hline CSRR*SHARIAH & & $-0.227(0.041)^{* *}$ \\
\hline Year dummies & Yes & Yes \\
\hline Industry (Bank) dummies & Yes & Yes \\
\hline Adjusted $\mathrm{R}^{2}$ & 0.556 & 0.501 \\
\hline F-statistics & $8.182(0.000)$ & $16.947(0.000)$ \\
\hline Endogeneity test ( $p$-value) & 0.000 & 0.000 \\
\hline White test ( $p$-value) & 0.000 & 0.000 \\
\hline Sargan test & 0.376 & 0.313 \\
\hline LM test (p-value) & 0.000 & 0.000 \\
\hline Obs. (Banks) & 270 & 270 \\
\hline No. of Banks & 30 & 30 \\
\hline
\end{tabular}

Notes: *Significance at $* 10 \%$ level; Significance at $* * 5 \%$ level; Significance at $* * * 1 \%$ level. Numerical figures in the parentheses are t-statistics.

Source: Author's calculation 
This study employs both panel fixed- Tables 6 and 7) show similar results that confirm effects and pooled panel OLS estimators as the uniformity of the main findings (Table 4) and another measure of the robustness to check the authenticity of the results shown in Table 4 . The unbiasedness of the two-step GMM estimations' outcomes of both estimations (represents in

outcomes.

Table 6: Robustness tests: alternative estimation methods (pooled panel ols instead of gmm estimator)

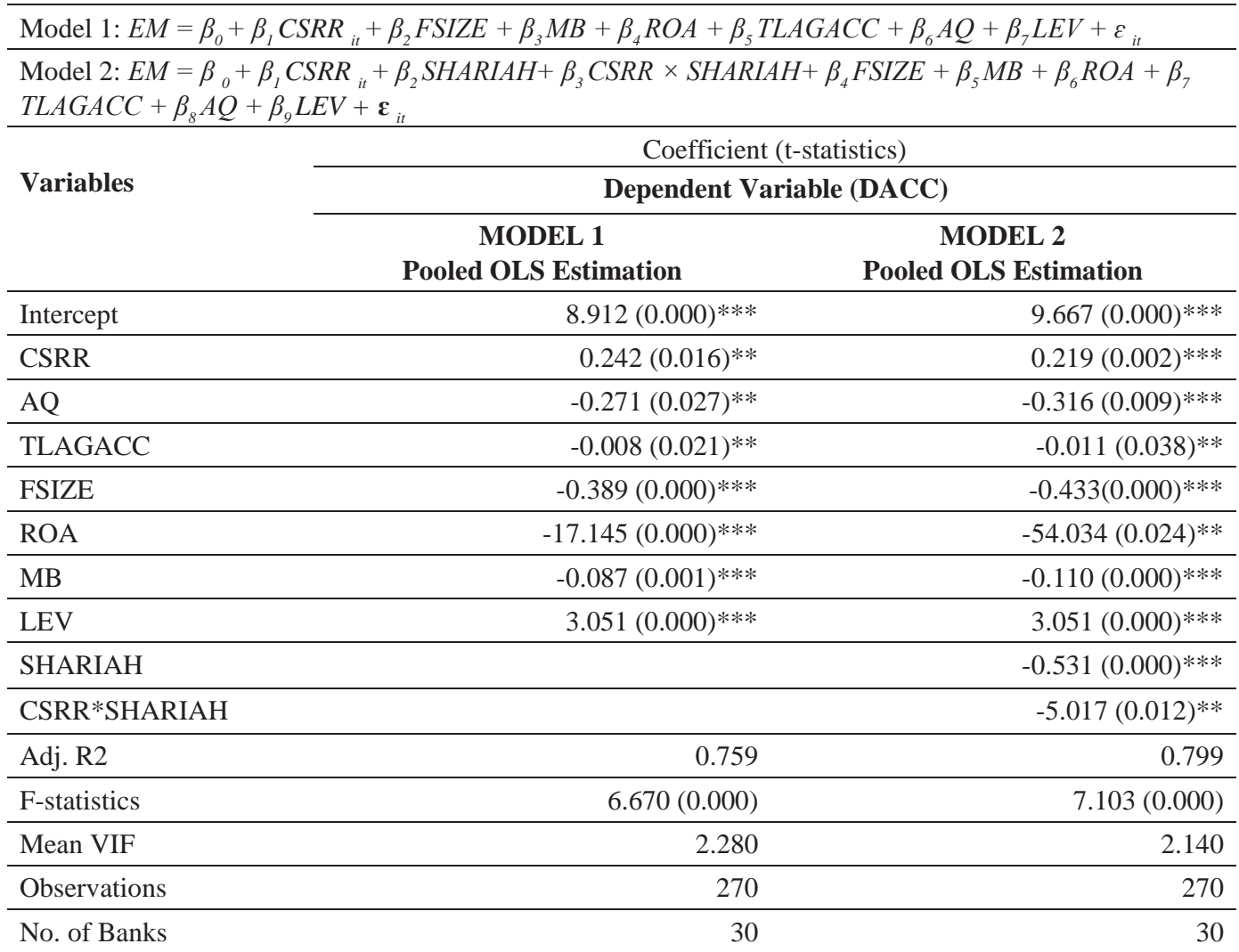

Notes: The numbers in parentheses are t-values.*, $* *$ and ${ }^{* * *}$ indicate significance at the $10 \%, 5 \%$ and $1 \%$ levels, respectively.

Source: Author's calculation 
Table 7: The result of multivariate regressions (FE Estimator instead of GMM Estimator)

\begin{tabular}{|c|c|c|}
\hline Model 1: $E M=\beta_{0}+$ & ${ }_{i t}+\beta_{2} F S I Z E+\beta_{3} M B+\beta_{4}$ & $A C C+\beta_{6} A Q+\beta_{7} L E V+\varepsilon_{i t}$ \\
\hline $\begin{array}{l}\text { Model 2: } E M=\beta_{0}+ \\
T L A G A C C+\beta_{8} A Q\end{array}$ & $\begin{array}{l}{ }_{i t}+\beta_{2} S H A R I A H+\beta_{3} C S R I \\
+\varepsilon_{i t}\end{array}$ & $\beta_{4} F S I Z E+\beta_{5} M B+\beta_{6} R O A+\beta_{7}$ \\
\hline & $\mathrm{Co}$ & tics) \\
\hline Variables & Depende & $L_{1}(\mathbf{D A C C})$ \\
\hline & MODEL 1 & MODEL 2 \\
\hline & Fixed Effect Estimation & Fixed Effect Estimation \\
\hline Intercept & $7.45(0.041)^{* *}$ & $3.880(0.020) * *$ \\
\hline CSRR & $0.890(0.006) * * *$ & $0.660(0.000)^{* * *}$ \\
\hline $\mathrm{AQ}$ & $-2.219(0.043) * *$ & $-1.469(0.028) * *$ \\
\hline TLAGACC & $-0.214(0.039) * *$ & $-0.202(0.041)^{* *}$ \\
\hline SHARIAH & & $-0.779(0.047)^{* *}$ \\
\hline CSRR*SHARIAH & & $-4.680(0.002) * *$ \\
\hline FSIZE & $-4.069(0.014) * *$ & $-2.719(0.037) * *$ \\
\hline ROA & $-8.071(0.002) * * *$ & $-1.191(0.000)^{* * *}$ \\
\hline $\mathrm{MB}$ & $-1.729(0.000)^{* * *}$ & $-2.219(0.000)^{* * *}$ \\
\hline LEV & $0.299(0.021)^{* *}$ & $0.296(0.003) * *$ \\
\hline Adj. $\mathrm{R}^{2}$ & 0.744 & 0.757 \\
\hline F-statistics & $5.787(0.000)$ & $4.623(0.000)$ \\
\hline Mean VIF & 2.280 & 2.140 \\
\hline Observations & 270 & 270 \\
\hline
\end{tabular}

Notes: Detailed definitions of all variables are given in Table 1. The numerical figures in parentheses are t-values. ${ }^{*}, * *$ and $* * *$ indicate significance at the $10 \%, 5 \%$ and $1 \%$ levels, respectively.

Source: Author's calculation

\section{Conclusion}

This study was based on two research objectives. The first objective of the study was to investigate the impact of corporate social responsibility reporting on earnings management. Hypotheses were formulated to test the effect of CSRR on earnings management. Results of the data analysis show that CSRR had a significant positive effect on discretionary accruals. More specifically, in line with the view that managers have the incentives to behave opportunistically and then use CSR disclosures to shift the focus of stakeholders from managerial opportunism, our results suggest a positive relation between the level of CSR disclosures and earnings management measured by discretionary accruals. The next objective of the study was to investigate the moderating effect of Shariah principles in association between CSR reporting and earnings management. Results of statistical analysis reveal that Shariah principles significantly and negatively moderate the relationship between CSRR and EM (for proxy, i.e., DACC) and the analysis supports the notion of the stakeholder salience theory. Overall, our results support the conjecture that there is a negative relationship between CSR and earnings management, and that the Shariah principles play a significant role on enhancing ethical activities and mitigating managerial opportunisms and also the results comply with the underlying concept of the stakeholder salience theory.

This study has several contributions. At the outset, this study is the first rigorous and comprehensive study to examine the impact of CSRR on EM in the Bangladeshi banking 
sector and the first study, per the researcher's knowledge, to construct a comprehensive CSRR index. Moreover, this study makes contributions towards CSR oriented businesses that are Shariah-compliant (Islamic Banks) by measuring whether Shariah-obedient banks perform morally by generating excellent financial reporting and conveying clear and dependable data to financiers. This study makes contributions (useful contribution) on the scientific debate on CSR reporting and earnings management from an Islamic moral viewpoint. Furthermore, prior studies show inconclusive outcomes regarding CSR reporting and eanings management nexus based on stakeholder and agency theoretical perspectives. To close this gap, this reseach incorporates stakeholder salience theory that describes this nexus as not only satisfying the demand from the diverse stakeholders but also the legitimate use of Shariah principles.

Besides, this study has several practical implications. This study supports current business non-financial reporting practices as well as policymakers should be careful concerning the opportunistic motives of the managers and developing a monitoring cell that ensure sustainability compliance. Also, the regulators should establish specific guidelines to check whether CSR revelations are based on authentic exercise or just a "greenwash" statement to mislead stakeholders. It could also help various stakeholders understand how reliable and transparent financial reporting is, in the light of the relation between Shariah principles, CSR and EM.

Moreover, this study has important practical implications to corporations, investors, investment advisors, policymakers, and regulators as well. In light of the study findings, regulators and policymakers can use such findings to propose and issue regulations that strengthen accruals management criteria and accordingly enhance transparent financial reporting quality. Furthermore, policymakers should promote Shariah-compliant firms because the finding implies that Shariah ethics restrict managers to use controversial mechanism through EM practices and also perform more CSR activities for the betterment of the society that may fulfil the societal commitment. Also, investment advisors can use the findings of the study in the process of cherry-picking their investment portfolios by investing in firms that adhere to good CSR initiatives and disclosure since managers may use entrenchment mechanism to deceive stakeholders.

Also, this study has provided avenues for further research. An example of such avenues is that EM by Bangladeshi banking companies is driven by the perspective of transparent financial reporting or opportunistic motive, but prior studies also advocate that managers might manipulate earnings due to speculative motive, altruistic motive, or pressure from associates. This could usually be acknowledged through a qualitative research technique using either a survey or a questionnaire-based approach. Furthermore, it may be worth leading this result by inspecting different sectors and institutional frameworks. Having just one independent variable could be a limitation of our study, as determining the CSR index involving subjectivity is an objective that should be addressed in future research. Furthermore, this study focused on the one-directional relationship between CSR and EM, hence this study could be extended by showing bi-directional relationship on this association in the banking sector. Besides, this research shows the moderating effect of Shariah principles that restrain the motives of EM, but previous studies stated that ownership structure and corporate governance also have significant impact to shrink EM practices. We expect a different connection between CSR reporting and earnings management when the large shareholders are institutions instead of individuals. Therefore, future study could be focused on these issues. Moreover, this research is aware that other regulations and standards have been developed concerning sustainability matters by several associations, in addition to the GRI guidelines. Thus, the hypothesis that was developed in this study could be considered in future research for different global guidelines 
based on sustainability issues such as UN global compact, WRI, ISO, and CDP, etc.

The study has some limitations that could be considered as avenues for future research. Cultural features may also have an effect. Meanwhile these findings are based on one country, which may affect the generalizability of these results. Further research along these lines may deliver motivating understandings. Moreover, this study focuses on the CSR disclosure of banking sector only. It would be stimulating to investigate the link between CSRR and earnings management for nonfinancial firms. Furthermore, since this outcome is inclined by accounting guidelines and legal restrictions, monetary circumstances and by the specificity of the banking sector, upcoming research could cover the investigation through incorporating other sectors and geographical areas. This study believes that the diversities in the different cultural and geographic regions and the extent of social and ecological risks in many sectors may also affect in the earnings management practices and CSR initiatives.

\section{Acknowledgements}

Authors wished to thank reviewers and editors for the comments on this article.

\section{References}

Abdelsalam, O. H., Dimitropoulos, P. E., Elnahass, M., \& Leventis, S. (2016). Earnings management behaviors under different monitoring mechanisms: The case of Islamic and conventional banks. Journal of Economic Behavior and Organization, 132, 155-173.

Ahmed, A. (2018). Corporate Social Responsibilities (CSR) of commercial banks in Bangladesh. (Doctoral dissertation, United International University).

Ali, M. M., \& Islam, A. M. (2014). Agribusiness potentials for Bangladesh - An analysis. The paper will be presented at the biennial conference on Rethinking Political Economy of Development, which held on 20-22 November, 2014, organized by Bangladesh Economic Association.

Alsaadi, Abdullah, Jaafar, Azis, \& Ebrahim,

M. S. (2013). Corporate social responsibility, Shariah-compliant and earnings management. Seventh Asia Pacific Interdisciplinary Research in Accounting Conference, 44(0), 1-48.

Amar \& Chakroun. (2018). Do dimensions of corporate social responsibility affect earnings management? Evidence from France. Journal of Financial Reporting and Accounting, 16(2), 348-370.

Amidu \& Kuipo. (2014). Earnings management, funding and diversification strategies of banks in Africa. Accounting Research Journal, 28(2), 172-194.

Arellano, Manuel, \& Olympia Bover. (1995). Another look at the instrumental variable estimation of error components models. Journal of Econometrics, 68, 29-51.

Arellano, Manuel, \& Stephen Bond. (1991). Some tests of specification for panel data: MonteCarlo evidence and anapplication to employment equations. Rev. Econ.Stud., 58, 277-297.

Azim, M. I., Ahmed, E., \& D’Netto, B. (2011). Corporate social disclosure in Bangladesh: A study of the financial sector. International Review of Business Research Papers, 7(2), 37-55.

Bangladesh Bank. (2008). Mainstreaming Corporate Social Responsibility (CSR) in banks and financial institutions in Bangladesh. June, Department of offsite supervision.

Belal, A. R., Cooper, S. M., \& Khan, N.

A. (2015). Corporate environmental responsibility and accountability: What chance in vulnerable Bangladesh? Critical Perspectives on Accounting, 33, 44-58. doi:10.1016/j.cpa.2015.01.005

Belal, A. R., \& Cooper, S. (2011). The absence of corporate social responsibility reporting 
in Bangladesh. Critical Perspectives on Accounting, 22(7), 654-667.

Blundell, Richard, \& Stephen Bond. (2000). Initial conditions \& moment restrictions in dynamic panel data models. Journal of Econometrics, 87, 115-43.

Boesso, G., \& Kumar, K. (2009). Stakeholder prioritization and reporting: Evidence from Italy and the US. Accounting Forum, 33, 162-175.

Breusch, T. S. (1978). Testing for autocorrelation in dynamic linear models. Aust. Econ. Pap., 17(31), 334-355.

Carnevale, C., \& Mazzuca, M. (2014). Sustainability report and bank valuation: Evidence from European stock markets. Business Ethics: A European Review, 23(1), 69-90.

Carroll, A. B. (1979). A three-dimensional conceptual model of corporate performance. Academy of Management Review, 4(4), 497-505.

Chahine, S., Fang, Y., Hasan, I., \& Mazboudi, M. (2019). Entrenchment through Corporate Social Responsibility: Evidence from CEO Network Centrality. International Review of Financial Analysis.

Chih, H., Shen, C., \& Kang, F. (2008). Corporate Social Responsibility, Investor protection, and earnings management: Some international evidence. Journal of Business Ethics, 79, 179-198.

Choi, B. B., Lee, D., \& Park, Y. (2013).

Corporate social responsibility, corporate governance and earnings quality: Evidence from Korea. Corporate Governance: An International Review 21(5), 447-467.

Cronbach, L. J. (1951). Coefficient alpha and the internal structure of tests. Psychometrika, 16(3), 297-334.

Das, S., Dixon, R., \& Michael, A. (2015). Corporate social responsibility reporting: A longitudinal study of listed banking companies in Bangladesh. World review of business research, 5(1), 130-154.
Duellman, S., Hurwitz, H., \& Sun, Y. (2015). Managerial overconfidence and audit fees. Journal of Contemporary Accounting and Economics, Forthcoming.

Eesley, C., \& Lenox, M. J. (2006). Firm responses to secondary stakeholder action. Strategic Management Journal, 27(8), 765-781.

Elasrag, H. (2015). Corporate Social Responsibility: An Islamic perspective. Munich Personal RePEc Archive MPRA 5. May 2015.

Elnahass, M., Izzeldin, M., \& Abdelsalam, O. (2014). Loan loss provisions, bank valuations and discretion: A comparative study between conventional and Islamic banks. Journal of Economic Behavior and Organization, 103, 160-173.

EPB. (2012). Bangladesh export data, available at: www.epb.gov.bd (accessed 20 April 2012).

Fortune. (2007). Fortune magazine's 2007 survey.

Freeman, R. E. (1984). Strategic management: A stakeholders approach.

Gargouri, R. M., Shabou, R., \& Francoeur, C. (2010). The relationship between corporate social performance and earnings management. Canadian Journal of Administrative Sciences/Revue Canadienne Des Sciences De l'Administration, 27(4), 320-34.

Godfrey, L. G. (1978). Testing against general autoregressive and moving average error models when the regressors include lagged dependent variables. Econometrica: J. Econom. Soc., 193-1301.

Gras-Gil, E., Palacios Manzano, M., \& Hernández Fernández, J. (2016). Investigating the relationship between corporate social responsibility and earnings management: Evidence from Spain. $B R Q$ Business Research Quarterly, 19(4), 289299. 
Grougiou, V., Leventis, S., Dedoulis, E., \& Owusu-Ansah, S. (2014). Corporate social responsibility and earnings management in U.S. banks. Accounting Forum, 38(3), 155169.

Gujarati, D. N., \& Porter D. C. (2008). Basic econometrics (5th ed.). New York: McGraw-Hill.

Hair, J. F., Black, W. C., Babin, B. J., Anderson, R. E., \& Tatham, R. L. (2006). Multivariate data analysis $\left(6^{\text {th }}\right.$ ed.). Upper Saddle River, NJ: Pearson Prentice Hall.

Haniffa, R. M., \& Hudaib, M. (2007). Exploring the ethical identity of Islamic banks via communication in annual reports. Journal of Business Ethics, 76(1), 97-116.

Hassan, R., \& Sharmin, H. (2015). Antecedents of earnings management among Islamic banks: Evidence from Bangladesh. PRA International Journal of Economic and Business Review, 3(4), 112-116.

Hong, Y., \& Andersen, M. L. (2011). The relationship between corporate social responsibility and earnings management: An exploratory study. Journal of Business Ethics, 104(4), 461-471.

Hossain, A., Bashar, K. A., \& Noor, B. (2017). The impact of Corporate Social Responsibility (CSR) on National and International corporations prevailing in Bangladesh: A comparison of CSR on the basis of Carroll's Pyramid. Journal of Investment and Management, 6(1), 6-12.

Hossain, M. S., \& Neogy, T. K. (2019). The current status of Corporate Social Responsibility disclosure of Islamic Sharibased Banking Companies in Bangladesh. American Journal of Trade and Policy, 6(1), 7-12.

Hye, H. A. (2020). The state of Bangladesh economy - 2019. The Financial Express, January 18, 2020.

IASCF (International Accounting Standards Committee Foundation). (2003).
International Financial Reporting Standards, London, UK.

Ibrahim, M. S., Darus, F., Yusoff, H., \& Muhamad, R. (2015). Analysis of earnings management practices and sustainability reporting for corporations that offer Islamic products and services. Procedia Economics and Finance, 28(April), 176-182.

Islam \& Kokubu (2017). Corporate social reporting and legitimacy in banking: A longitudinal study in the developing country. Social Responsibility Joiurnal, 14(1), 159-179.

Jones, J. (1991). Earnings management during import relief investigations. Journal of Accounting Research, 29(2), 193-228.

Jones, M. J. (2011). Creative accounting, fraud and international accounting scandals. Chichester, West Sussex, England: John Wiley \& Sons.

Khan, A. R., \& Akter, M. (2017). An analysis of earnings management: Evidence from food \& allied industry of Bangladesh. International Journal of Accounting and Financial Reporting, 7(2), 359-372.

Khan, H. U. Z., Halabi, A. K., \& Samy, M. (2009). Corporate social responsibility (CSR) reporting: A study of selected banking companies in Bangladesh. Social Responsibility Journal, 5(3), 344-357.

Kibria, A. (2020). BD economy may grow by 7.80 pc in FY20: UN. UN World Economic Situation and Prospects (UN WESP), January 17, 2020.

Kilic, M., Kuzey, C., \& Uyar, A. (2015). The impact of ownership and board structure on Corporate Social Responsibility (CSR) reporting in the Turkish banking industry. Corporate Governance: The International Journal of Business in Society, 15(3), 357374.

Kim, Y., Park, M. S., \& Wier, B. (2012). Is earnings quality associated with Corporate Social Responsibility? The Accounting Review, 87(3), 761-796. 
Klein (2002). Audit Committee, Board of Director characteristics, and earnings management. Journal of Accounting and Economics, 33(3), 375-400.

Kolsi, M. C., \& Grassa, R. (2017). Did corporate governance mechanisms affect earnings management? Further evidence from GCC Islamic banks. International Journal of Islamic and Middle Eastern Finance and Management, 10(1), 2-23.

Leventis, S., \& Dimitropoulos, P. (2012). The role of corporate governance in earnings management: experience from US banks. Journal of Applied Accounting Research, 13(2), $161-177$.

Maali, Bassam, Casson, Peter, Napier, \& Christopher. (2006). Social reporting by Islamic banks. Abacus, 42(2), 266-289.

Masud, M. A. K., \& Kabir, M. H. (2016).

Corporate social responsibility evaluation by different levels of management of Islamic banks and traditional banks: Evidence from banking sector of Bangladesh. Probl. Perspect. Manag, 14, 194-202.

Mersni, H., \& Othman, H. Ben. (2015). The impact of corporate governance mechanisms on earnings management in Islamic banks in the Middle East region. Journal of Islamic Accounting and Business Research, 7(4), 318-348.

Mitchell, R. K., Agle, B. R., \& Wood, D. J. (1997). Towards a theory of stakeholder identification and salience: Defining the principle of who and what really counts. Academy of Management Review, 22(4), 853-886.

Moudud-Ul-Huq, S. (2019). Can BRICS \& ASEAN-5 emerging economies benefit from bank diversification? Journal of Financial Regulation and Compliance, 27(1), 43-69.

Muttakin, Khan \& Mihret (2017). Business group affiliation, earnings management and audit quality: Evidence from Bangladesh.
Managerial Auditing Journal, 32(4/5), 427444. DOI 10.1108/MAJ-01-2016-1310

Muttakin, M. B., \& Khan, A. (2014). Determinants of corporate social disclosure: Empirical evidence from Bangladesh. Advances in Accounting, 30(1), 168- 175.

Muttakin, M. B., Khan, A., \& Azim, M. I. (2015). Corporate social responsibility disclosures and earnings quality. Managerial Auditing Journal, 30(3), 277-298.

Neill, J. D., \& Stovall, O. S. (2005). Stakeholder Salience and Corporate Social Responsibility: Evidence from three companies. Journal of Applied Business Research (JABR), 21(3). doi.org/10.19030/ jabr.v21i3.1470

Pfeffer, J. (1981). Power in organizations. Marshfield, MA: Pitman.

Prior, D., Surroca, J., \& Tribó, J. A. (2008). Are socially responsible managers really ethical? Exploring the relationship between earnings management and Corporate Social Responsibility. Corporate Governance: An International Review, 16(3), 160-177.

Rahman, M., \& Chowdhury, S. (2019). Sustainability reporting and firm financial performance: A review of measurement tactics. International Journal of Engineering Development and Research (IJEDR), 7(4), 723-730.

Rahman, M. M., Zheng, C., Ashraf, B. N., \& Rahman, M. M. (2018). Capital requirements, the cost of financial intermediation and bank risk-taking: Empirical evidence from Bangladesh. Research in International Business and Finance, 44(May 2017), 488-503.

Rahman, S. (2017). Role of government in the promotion of Corporate Social Responsibility (CSR): The case of Bangladesh banking sector. Australian Academy of Accounting and Finance Review, 1(1), 4468.

Scholtens, B. (2009). Corporate Social Responsibility in the International Banking 
Industry. Journal of Business Ethics, 86(2), 159-175.

Sobhani, F. A., Amran, A., \& Zainuddin, Y. (2012). Sustainability disclosure in annual reports and websites: A study of the banking industry in Bangladesh. Journal of Cleaner Production, 23(1), 75-85.

Suyono, E., \& Farooque, O. Al. (2018). Do governance mechanisms deter earnings management and promote corporate social responsibility? Accounting Research Journal, 31(3), 479-495.

Tafti, S. F., Hosseini, S. F., \& Emami, S. A. (2012). Assessment the Corporate Social Responsibility according to Islamic values: A case study of Sarmayeh Bank. ProcediaSicial and Behavioral Sciences, 58(2012), 1139-1148.

Thijssens, T., Bollen, L., \& Hassink, H. (2015). Secondary stakeholder influence on CSR disclosure: An application of Stakeholder Salience Theory. Journal of Business Ethics, 132, 873-891. doi.org/10.1007/ s10551-015-2623-3

Ullah, M. H., \& Rahman, M. A. (2015). Corporate social responsibility reporting practices in banking companies in Bangladesh. Journal of Financial Reporting and Accounting, 13(2), 200-225. doi:10.1108/jfra-05-20130038

Watts, R. L., \& Zimmerman, J. L. (1978). Towards a positive theory of the determination of accounting standards. The Accounting Review, 53(1), 112-134.

White, H. (1980). A heteroskedasticityconsistent covariance matrix estimator and a direct test for heteroskedasticity. Econometrica: J. Econom. Soc., 817-838.

Yasuda, Y., Okuda, S., \& Konishi, M. (2004). The relationship between bank risk and earnings management: Evidence from Japan. Review of Quantitative Finance and Accounting, 22(3), 233-248.

Yip, E., Staden, C. V., \& Cahan, S. (2011). Corporate Social Responsibility Reporting and earnings management: The role of political costs. Australasian Accounting Business and Finance, 5(3), 17-34.

Zainuldin, H. M., \& Lui, T. K. (2018). Earnings management in financial institutions: A comparative study of Islamic banks and conventional banks in emerging markets. Pacific-Basin Finance Journal (July 2017). 


\section{APPENDIX A}

CSR Reporting Index (Total Disclosure Items = 42)

\begin{tabular}{ll}
\hline SL & 1st Dimension: Economic Disclosures \\
\hline 1 & Contribution to national exchequer \\
\hline 3 & Information concerning remittance collection \\
\hline 4 & Comparative financial growth with previous years \\
\hline 5 & Other economic disclosure \\
\hline & 2nd Dimension: Environmental Disclosures \\
\hline 6 & Investing in renewable energy \\
\hline 7 & Information concerning energy consumption (Gas/Fuel/Electricity) \\
\hline 8 & Energy Indirect Greenhouse Gas (GHG) Emissions \\
\hline 9 & Corporate environmental policies \\
\hline 10 & Environmental financing such as 'ecological credits' \\
\hline 11 & Green Banking and Environmental / Green Banking awards \\
\hline 12 & Solar panel distribution to the poor people and use of Solar panel in office \\
\hline 13 & Providing online information to reduce pollution \\
\hline 14 & Climate change risk fund \\
\hline 15 & Low interest rates for green projects \\
\hline 16 & Issues concerning climate change \\
\hline 17 & Certified environmental management system/ Environmental certification (e.g. ISO-14001) \\
\hline 18 & Promoting environmental sustainable output practices and lifestyles \\
\hline & $3 r d$ Dial performance \\
\hline 3
\end{tabular}

\section{3rd Dimension: Social Disclosure}

19 Credit facilities for women entrepreneurs or initiative to empowering woman;

20 Helping disadvantaged people;

19 Observation of various national ceremonies

20 Support to the foreign victims;

21 Heritage preservation

22 Special care for NRBs (Non-Resident Bangladeshi's)

23 Heritage preservation

24 Special care for NRBs (Non-Resident Bangladeshi's)

25 Conferences on Islamic economics; 
26 Commitments in operating within Shari'ah principles/ideals

27 Establishment of health care center for rural people for free medical services

28 Sponsoring in medical research

29 Establishment educational institutions (Schools, College, Madrasha, Libraries; Laboratory);

30 Patronizing general and technical education;

31 Donation to the universities for constructing research center;

32 Employee compensation, welfare or donation

33 Executive profile/list of corporate senior officials

34 Training employees through in-house programmes (e.g. leadership program; disability antidiscrimination program or career development programs)

35 Reward/ Promotion and recognition for better performance ;

36 Healthy and safe workplace for staff

37 Disclosure on child labour or free from child labour

38 Equal opportunity;

39 Different types of products and services (Glossary/definition of products)

$40 \quad$ Research and development' for products and services

41 Policy and compliance mechanism for protecting financial privacy of customers ;

42 Procedures for assessing and screening environmental and social risks in business lines 


\section{APPENDIX B}

Test of Non-Stationary

\begin{tabular}{|c|c|c|c|}
\hline Variables & Measurement Scales & $\mathrm{X}^{2}$ & p-Value \\
\hline CSRR & $\begin{array}{l}\text { Corporate Social Responsibility Reporting index based on } \\
\text { GRI guidelines and prior studies. }\end{array}$ & 134.444 & 0.0000 \\
\hline LEV & The proportion of debts to total assets & 125.774 & 0.0000 \\
\hline FSIZE & The natural logarithm of total assets & 96.6992 & 0.0019 \\
\hline ROA & Return on average assets & 407.794 & 0.0000 \\
\hline MB & Market to Book value ratio & 85.6359 & 0.0166 \\
\hline DACC & Discretionary accruals & 113.566 & 0.0000 \\
\hline TLAGACC & The lagged total accruals & 169.064 & 0.0000 \\
\hline DAAC $_{t-1}$ & the one year lagged of Discretionary accruals & 113.566 & 0.0000 \\
\hline CSRR*SHARIAH & $\begin{array}{l}\text { interaction variable of corporate social responsibility } \\
\text { reporting and SHARIAH }\end{array}$ & 220.382 & 0.0000 \\
\hline
\end{tabular}

Notes: The table shows the augmented dickey fuller test-fisher type (which is applicable for both balanced/ Unbalanced panel) results where the null of non-stationarity have been rejected for all the variables at $95 \%$ confidence level. In case of dummy variables (all values lie between 0 and 1), this test is not required. 